\title{
Research on Teaching Method Reform in Application-oriented Undergraduate Universities
}

\author{
Jiangbo Chen \\ Qingdao Huanghai University \\ Qingdao, Shandong, China \\ jiangbochen1981@163.com
}

Yan $\mathrm{Li}^{*}$

Qingdao Economic \& Technological Development Area No.2

Experimental Primary School

Qingdao, Shandong, China

\author{
Yuanyuan $\mathrm{Xu}$ \\ Qingdao Huanghai University \\ Qingdao, Shandong, China
}

\author{
Rui Xue \\ Qingdao Huanghai University \\ Qingdao, Shandong, China
}

\begin{abstract}
Since the higher education system transfer from "elite higher education" to "mass higher education" in china. The application-oriented undergraduate university students' academic interests and their aspiration of curiosity have declined obviously. Due to the lagging reform of teaching moehod, university students begin to lose interest in it. Hence, in order to cater for the need of students, the application-oriented universities should adjust themself, and strengthen the teaching method reform. How to improve students' Professional quality, how to arouse their interest, and how to strength the efficiency are the questions that the teachers are always exploring and at the same time, is the focus of this research. Based on this phenomenon, the author takes the engineering specialty of Qingdao Huanghai University as an example, based on the analysis of effective teaching theory and the related literature both at home and abroad. This paper expounds the present situation and existing problems of classroom teaching and puts forward the strategy to enhance the effectiveness of classroom teaching.
\end{abstract}

Keywords-Teaching method; Self-learning ability; Teaching reform; Application-oriented undergraduate university

\section{INTRODUCTION}

Classroom teaching is a basis of university education, which is the main way for students to receive higher education. Professor Zhong Qiquan has said, "Only the educational reform starts with classroom teaching, which could be possible effective classroom creating and new learning community creating." The core of improving higher education quality is improving talent cultivating quality, and the key of improving talent cultivating quality is improving the quality of teaching. So we need to start with classroom teaching to carry out the effective teaching and comprehensive teaching reform. Improve teaching effect and achieve the improving of talent cultivating quality. Nowadays, the teaching effect of universities' classroom teaching is inefficient, affected by traditional teaching model, which is unable to satisfy the need for high-quality creative talent [1]. How to improve students' professional quality, how to arouse their interest, and how to strength the efficiency are the questions that the teachers are always exploring and at the same time, is the focus of this research.

The curriculum reform falls into three parts according to the most concerned subjects in the teaching front line. The first one is the evaluation of course programming, which focuses on how to evaluate teaching plans and course standards in the project-based curriculum. The second one is the evaluation of course teaching, which probes into the problem how to evaluate a teacher teaching designs, lecturing design and teaching capability in the projected course system. The third one is the evaluation of the students, which studies the evaluation of the students' vocational skills and professional quality. In the designing concept, it should establish new evaluation standards according to the request of project-based curriculum [2]. The standards are the following three. First, it should underscore the "ability goals" in the course evaluation of vocational course; and change the former "aims at telling knowledge" evaluation standard. Second, the evaluation of the course result should orient in the students instead of the teachers; while during the evaluation process, the students should be motivated sufficiently to practice by themselves. Third, it should choose proper task training exercises to evaluate; while during the evaluation, there should be specified targets for the students to fulfill the duty in the position, so that they learn the problem solving ability and self learning ability, then they can master the related knowledge and gain the actual achievements which can be taken as the testing standards.

Based on the above content, according to constructing principles of college class teaching mode, we try to construct several teaching modes which suit for the training of applied talents, by exploring new pathes, innovative talent training models, to explore suitable teaching mode for the sustainable development of application-oriented undergraduate education. 


\section{FLIPPED CLASSROOM TEACHING MODE}

This new teaching idea of flipped classroom originated from the United States, is based on the teaching model under the guidance of the constructivist learning theory, which embodies the teaching philosophy of "student-centered and teacher-oriented", which is helpful to stimulate students' interest in active learning, to improve the enthusiasm of students, increase student participation, training and improve students' ability of autonomous learning, ability to explore and analyze the ability to solve problems.

With the introduction and application of the flipped classroom teaching mode, a new direction has appeared in the process of education reform. Flipped classroom mode has been gradually received and recommended by more and more teachers, researchers and all other educators. It has been used in various stages of teaching, changing the transferring and processing of knowledge. The application of flipped classroom teaching mode makes passive learning transferring into meaningful learning, which has greatly guaranteed the teaching effect. As a kind of teaching resources, project cases can help the students understand the knowledge more quickly before the class. The implementation of the project task is helpful for the students to internalize and consolidate the knowledge.

Teaching process is divided into two modules ,pre-class and in-class, by flipped classroom teaching mode, Pre-class section is including teachers' teaching preparation and students learning, In-class section contains questions, the creation of scenarios, group learning, group cooperation, the results show, feedback evaluation, Concentration, succinctly interpretation, formative evaluation, and other aspects. Teachers provide learning resources for learners, learning resources is presented by micro-video, and digestion and learners independently complete the learning task before class. Teachers and students spent a lot of time communicating in the classroom. In the classroom, by collaboration, discussion, answering questions and other activities, learners have deep understanding of the knowledge. At the same time, some course present teaching information with mobile client, and supports students learning before class, in class and after class. Students can use the platform learning curriculum content independently. In class, through educational APP, students can get into task learning, problems-solving and summarize. After class, through educational APP, students can communicate and discuss with partners, and share their experiences, etc. Educational APP can effectively promote the fusion of students, teaching content and the classroom teaching, it will promote the big changes of traditional learning styles, teaching ideas and teaching modes [3].

There is guidance of autonomous learning in every class which offers study guide, clarifies learning task, set up the topic for discussion and arranges the self-evaluation. When autonomous learning is done, students need to send the assignment in guidance of autonomous learning to assistant teacher in photograph by QQ, and the assistant teacher will fed back the problems from students to teacher. The main contents in classroom teaching contains discussion, explanation about the emphasis and difficulty, reflection and consolidate are setting after class. The teaching mode turn over the traditional teaching mode, use the sequence to learn before to teach, is benefit to cultivate and improve the ability of autonomous learning.

\section{STUDIO TEACHING MODEL}

Studio teaching model originated "Workshop training" teaching in Germany, and there are a lot of successful teaching experiences in foreign art designing college. Our country began introducing studio teaching mode in art teaching reform in the 1950, 60s and such model are widely used in art courses in many vocational colleges.

The studio teaching organically integrates classroom teaching with production practice; focus on students; bases on curriculum knowledge; emphasizes "learning by doing and learning in production", which is completely in line with the basic characteristics of vocational education. In studio teaching, teachers lead students to take part in project; the teaching objectives consist with industry standards; students understand industry standards and work process through whole journey participation in project implementation and form the professional quality of systematic thinking. This is in accordance with the talent cultivate target of applicationoriented undergraduate universities [4].

Studio teaching was organized in small class in Qingdao Huanghai University. Teaching is in the form of training in rotation and project practical experience, practical teaching goal should be designed on the basis of decomposition of occupation ability; practical teaching content should design real job task into students' practical task; practical teaching process should choose the flexible teaching methods, and turn it into the process of students' learning; practical teaching evaluation should highlight the "authenticity", and evaluate the performance of students training process. Two ways can be introduced to run the studio, classroom operation and outside operation. Classroom operation is mainly to simulate real project work. Pick up typical tasks in real work and simulate in classroom teaching, focused on starting from the market. According to the requirements of jobs and career competence, constructing curriculum system based on working process systematization. Outside operation is mainly composed of productive practice project. Undertake real work projects during the operation of studio and mainly conducted outside of the classroom. Studio teaching adopts multiple evaluation modes, including school evaluation, industry evaluation and customer evaluation. And the evaluation will be brought into moral evaluation appraise system at the same time.

\section{TASK BASED LEARNING MODEL}

Task based Learning is a learning method based on Constructivism. The teacher design course task with knowledge to be learned, by which to achieve the objective that students master knowledge by complete the task. While in solving task, the students analyze task, raise questions and study plan to solve the questions, and finally achieve the objective through practice. The cooperative learning means all relative acts during cooperation of students in form of groups, maximizing all learning achievements to achieve common learning objective under certain incentive mechanism. 
As an application-oriented undergraduate university teacher, the author found that the traditional process of teaching and learning in professional courses, usually is first teaching contents of theoretical knowledge detailed, then introduce how to use these knowledge based on skill training. When learning the basic knowledge, students often fail to understand the abstract teaching content, monotone linear teaching method makes students lack the patience and interest, and cannot apply these basic knowledge [5]. Therefore, based on the education theory of technology support, to explore a kind of jointly study group structure for the organization, help students into the taskdriven learning environment, the formation of a stable student role group model is of great significance.

Based on practice and analyzing the theory of educational technology, the team define this organization model as task driven-peer student support instruction model, also explore it from two parts including theory and practice.

(1)Build curriculum system based on working process systematization.

(2)Select work projects throughout the teaching process. work.

(3)Analyze the relationship between project and course

(4)Regroup knowledge module of the course which related throughout the project knowledge.

(5)Work out the corresponding curriculum standard.

(6)Introduce enterprise real project, effectively carry out the practice teaching.

(7)Use the action-oriented teaching method, which was featured of student-centered, teacher led project, task driven, role-splay, etc

(8)Carry out the diversified evaluation, which was composed of self-evaluation of students by teachers and students mutual, industry evaluation, evaluation of enterprise based on the diversity of students learning process evaluation.

\section{(9)Develop effective database of project teaching resource.}

This research organize the details of peer student support instruction model by using the instruction model theory, also finish the classroom teaching model based on vocational education theory and constructivism theory. It includes the following steps: teachers design the guiding and inspiring learning tasks, set a fixed learning group, they discuss with each other, forming a learning partner organizations, groups often have a fast learning knowledge master students play the role of teachers, and the team students discuss, solve the difficulties in learning. The students' learning motivation has been stimulated, peer education interaction and self-exploration consciousness have been cultivated [6].

\section{V. "MODUlaR TEACHING" MODEL}

"Modular Teaching" is a teaching model that consist of a number of self-contained teaching modules. Each module is an independent learning "unit" that has its own logic structure. Modules make a "course" when they are selected and arranged according to certain logic. As a student-centered model, modular teaching is characterised by self-consistency, independence, hierarchy and openness.

The idea of modularization is applied into teaching design of College Sudents' Careers Development and Guidance in Qingdao Huanghai University and the previous "disciplinebased" teaching system is broken down. According to college students' psychological development rules and the needs of employment practice, modular teaching reintegrates eaching resource into modules with cumulative progression which feature employment preparations and career development. Through learning in each module, students are able to acquire employment knowledge and skills and form the idea of lifelong career development. In terms of process, the modular teaching design runs throughout the whole university life from start to graduation. Based on learning, psychological characteristics and needs of students in different stages, the design is aimd to provide teaching and guidance accordingly. In terms of the educaitonal body, course convenors, specialized teachers, instructors, student groups and social forces are all that can be relied upon. In terms of the teaching content, a cluster of modules are to be set up on the basis of the four topics. As for teaching resourses, various teaching resources are integrated by information resources (especially information network). The modular teaching design for the course of College Students' Careers Development and Guidance is based on the career planning theory, tsystematic teaching design theory and the main body interrelationship theory. It is a combination of systematicness and dialectics, development and balance, presupposition and generation, and modularization and optimization [7].

The modular teaching design for the course of College Students' Careers Development and Guidance is composed of teaching idea design, teaching objective design, modular teaching content design, modular teaching methods design and teaching evaluation design. Teaching idea design is about ideas like "skillful and knowledgeable" professionals and "allround"happy people. Teaching objective design clarifies teaching objective, analyzes teaching objective and students characteristics. Modular teaching content design ncludes career development, employability improvement and job hunting skills. Modular teaching methods design can be realized by lecturing, simulation and grouping methods. Teaching evaluation design includes the contents and methods for evaluation. 


\section{SUMMARY}

The development of students' learning autonomy is not achieved overnight. Therefore, teachers should make develop students' learning autonomy as its ownduty; they should transfer teaching ideas by changing the "excessive teaching" to giving students autonomy, combine self-learning and cooperation learning deeply, guide students to change learning behavior, and need to trust and encourage students (including care, respect, entrusts with an important task and the establish incentive mechanism, etc.). Thus, students' learning autonomy can get long-term development.

A brand-new reform is being faced by class teaching organizations and the implementation of curriculum of tourism in the application-oriented undergraduate universities, it is ought to be a breakthrough of teaching, it is necessary to further highlight the dominant position of students, to match the actual working position successfully, to cater the actual need of tourism industry, purpose of the consistent of the teaching process and the production process in the actual class teaching of application-oriented undergraduate universities, to change the previous two-step mode of theoretical teaching and practical teaching, to break through the bottleneck of traditional classroom teaching of talent cultivation.

\section{ACKNOWLEDGMENT}

This work was financially supported by the Teaching Reform Research Projects of Vocational Education in Shandong Province (NO.2017549), the Teaching Reform Research Projects of Qingdao Huanghai University (NO.2016jiaoxue06).

\section{REFERENCES}

[1] Dang Jianning, Yang Xiaohong. Flipped Classroom Mode under Internet Thinking: Its Value and Design Innovation [J]. E-Education Research, 2017(11):108-114.

[2] Li Mingli, Wang Liying, Jiang Yingtian,etc. Projection of centralized style teaching reform for undergraduate courses in colleges and universities $[\mathrm{J}]$. Experimental Technology and Management, 2017(1):203-205.

[3] Song Jinfan, Guo Xinfeng, Shi Mingjie,etc. Application of flipped classroom in university physics experiment teaching $[\mathrm{J}]$. Experimental Technology and Management, 2015(3):33-39.

[4] Yu Hongtao. Case Study on Blended Teaching Reform Effects Evaluation of Higher Education [J]. China Educational Technology, 2017(11):129-133.

[5] Liu Bao, Li Zhen-gang, Ruan Bo-xing. College Classroom Teaching Mode Reform Based on Engineering Education Accreditation [J]. Heilongjiang Researches on Higher Education, 2017(4):157-160.

[6] Xu Kuihong. The Connotation and Characteristics of MOOC and Its Enlightenments to Lifelong Education in China $[\mathrm{J}]$. Vocational and Technical Education, 2014(28):60-63.

[7] GuoYulian. On the Reform of Classroom Teaching Mode [J]. Theory and Practice of Education, 2012(10):57-60. 